\title{
Exploring Frontiers in Electronic Evidence: The Philippine Experience
}

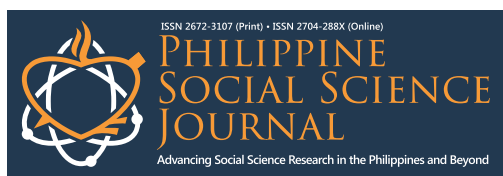

Janice L. Andrade-Udarbe ${ }^{1}$ and Constantino T. Ballena ${ }^{2}$

${ }^{1}$ Presiding Judge, RTC Branch 57, Lucena City, Quezon, Philippines

${ }^{2}$ De la Salle University-Dasmariñas, Dasmariñas City, Philippines

\section{Article history:}

Submitted: 26 August 2021

Revised: 20 November 2021

Accepted: 21 December 2021

\section{Keywords:}

Basic qualitative research

Electronic evidence

Rules on electronic evidence

National Capital Region-Cavite

ABSTRACT. This paper is the first formal empirical study on electronic evidence (EE) since the promulgation of Rules on Electronic Evidence (REE) by the Philippine Supreme Court in 2001. Basic qualitative research design was employed in the study. A total of 29 litigation lawyers and 13 trial judges from the Province of Cavite and the National Capital Region were the participants in the study. A qualitative survey questionnaire was used to gather data from the participants through Google Docs. Results showed that EE was more commonly presented in criminal cases, a few in civil cases, and none in quasi-judicial and administrative cases. Text messages were found to be the most frequently presented EE at trial. Results further revealed three major themes such as (1) admissibility of $\mathrm{EE}_{\text {, }}$ (2) authentication of $E E$, and (3) suggestions on the implementation of REE. The vagueness of REE provisions on the admissibility of electronic evidence results in varying interpretations of judges, which ultimately affect their appreciation of the evidence presented at a trial. The present empirical study would indeed contribute to the scholarly discourse of electronic evidence showcasing the Philippine experience.

\subsection{Introduction}

Studies on electronic evidence present varying descriptions of the nature of electronic evidence based on their respective jurisdictions. Under the jurisdictions of Malaysia and the United Kingdom, "Electronic evidence essentially denotes the type of evidence generated electronically and very often created by a computer or machine" (Mohamad, 2019, p. 121). In the United States of America, electronic or digital evidence encompasses information stored in or transmitted by a computer device, flashcard in digital cameras, mobile phones, CD, and the like (Novak et al., 2018). Across jurisdictions, electronic evidence is deemed to refer to "any information generated, stored or transmitted in digital form that may later be needed to prove or disprove a fact disputed in legal proceedings" (Kančauskienè, 2019, p.11).

Essentially, different jurisdictions are guided by their respective laws or legislation concerning the admissibility of electronic evidence in the courts of law and its authenticity. The two central aspects of electronic evidence are subject not only to scholarly discourse but, more importantly, to legal and administrative proceedings (Didace, 2021; Jackson, 2021; Kančauskienè, 2019; Khudhair, 2021; Makulilo, 2018; Mohamad, 2019; Novak et al., 2018; Tosza, 2020). Studies on the admissibility and authenticity of electronic evidence have been conducted in Tanzanian jurisdiction (Makulilo, 2018; Didace, 2021), in Indian jurisdiction (Khudhair, 2021), in Malaysia, and the UK jurisdictions (Mohamad, 2019), and Lithuanian jurisdiction (Kančauskienè, 2019).

The adoption of the rule of law related to the admissibility of electronic evidence varies from one country to another. In some countries, electronic evidence is more strictly regulated in the area of criminal law, mainly due to differences in the weight of the evidence required in a criminal case and a civil case. The Dutch Code of Civil Procedure provides that evidence can be given using any means. The judge can freely evaluate the evidence. In Belgium, digital evidence can be excluded if it is obtained by violating the right to privacy or by committing a criminal offense. In practice, invoking these grounds seldom leads to the inadmissibility of the evidence (Kramer, 2018). Another example is Poland's Code of Civil Procedure, which contains several rules relating to electronic documents, records of images, sound or image, and sound. ${ }^{1}$ England and Wales seem to be the only European

${ }^{1}$ Article 245 and 308 of the Polish Code of Civil Procedure (2014).

This article published by Philippine Social Science Journal (PSSJ) is licensed under a Creative Commons AttributionNoncommercial 4.0 International (CC BY-NC 4.0). You are free to share (copy and redistribute the material in any medium or format) and adapt (remix, transform, and build upon the material). Under the following terms, you must give appropriate credit, provide a link to the license, and indicate if changes were made. You may do so in any reasonable manner but not in any way that suggests the licensor endorses you or your use. You may not use the material for commercial purposes. 
countries with the most widely inclusive framework in place regarding electronic disclosure. ${ }^{2}$

In the United States, electronic evidence and electronic discovery are well-regulated at the federal level, aside from the different laws passed by each state. According to the study of American Bar Association, ${ }^{3}$ the use of electronic evidence in the United States has become vital. In addition to computer records, critical evidence may also come from internet websites, chat rooms, application program files, and e-mails. In Canada, on the other hand, the presentation of electronic evidence and electronic discovery is regulated at both the federal and provincial levels. ${ }^{4}$ In the Asian region, a number of countries have also adopted rules regarding electronic evidence. For instance, China has adopted, since 2012, rules on electronic evidence in both criminal and civil procedure laws (Wang, 2008). Japan considers electronic evidence as traditional evidence. The "Criminal Procedure Act of Japan" is the applicable law, which allows for electronic evidence in courts, provided that the legality of collected evidence must be ensured. In Malaysia, "The Electronic Commerce Act 2006" defines electronic data and information and provides them the same value as traditional information. Lastly, in India, the "Information Technology Act", enacted in 2000, provides electronic documents the same level of admissibility as traditional documents.

The Philippines is among the countries that adapt to the fast-changing world of technology. Legislators have deemed it necessary to enact R.A. No. 8792, or the "Electronic Commerce Act" (ECA), which was signed into law in 2000. Shortly thereafter, the Supreme Court promulgated in 2001 the "Rules on Electronic Evidence" (REE) in answer to the enactment of R.A. No. 8792. ECA and REE have become a legal framework that addresses various concerns relative to electronic documents and transactions. As to its applicability, REE applies to any kind of data message and electronic document used in the context of commercial and non-commercial activities to include domestic and international dealings, transactions, arrangements, agreement contracts, and exchange and storage of information. ${ }^{5}$ Under the Philippine jurisdiction, REE applies to all civil actions and proceedings, quasi-judicial and administrative cases, ${ }^{6}$ and criminal proceedings. ${ }^{7}$

REE has already been in effect for almost 20 years; however, there has been a dearth of cases decided by the Supreme Court that interprets the relevant provisions of said rules, viz., Ang v. Court of Appeals ${ }^{8}$, People v. Enojas ${ }^{9}$, MCC Industrial Sales Corp. v. Ssangyong Corp., ${ }^{10}$ People v. Vitangcol III, ${ }^{11}$ Aznar v. Citibank, ${ }^{12}$ Nuez v. Cruz-Apao, ${ }^{13}$ and Vidallon-Magtolis v. Salud. ${ }^{14}$ While the rules have laid down the guidelines for appreciating electronic evidence, in the decisions rendered by the Supreme Court, there appear to be variations in the interpretation and application of REE. In addition to the dearth of jurisprudential cases on REE application, there has been no formal empirical study on electronic evidence, its application, and usage in the courts of law. Thus, this present research, an exploratory study on the frontiers in electronic evidence under the Philippine jurisdiction, was undertaken. The present empirical study would indeed have a valuable contribution to the scholarly discourse of electronic evidence showcasing the Philippine experience.

The present study explored the frontiers of REE in light of the actual practice of law based on the experiences of the participant trial court judges and litigation lawyers. Specifically, the study focused on the application and use of electronic evidence in judicial proceedings. It aimed to unravel what judges and lawyers say about the type of electronic evidence presented in court, the criteria set by law for the admissibility of electronic evidence, authentication of the electronic evidence and its admissibility, and procedures in different courts with respect to the application of the "Rules on Electronic Evidence."

\footnotetext{
${ }^{2}$ The primary provisions are laid down in CPR 31 and supplemented by Practice Direction 31B dealing with electronic disclosure. 45 The primary federal rules are contained in FRCP, Rule 16, 26, 30, 33, 34, 37, 45.

${ }^{3}$ ABA 2006.

${ }^{4}$ The Sedona Canada Principles (2015), Sedona Conference Working Group 7, 2008 CanLIIDocs 1, <https://canlii.ca/t/nf>, retrieved on 2021-11-25.

${ }^{5}$ Republic Act No. 8792 (2000), Sec. 4.

${ }^{6}$ Rules on Electronic Evidence, Rule 1, Sec. 1.

${ }^{7}$ Supreme Court Resolution, No. 01-7-01-SC (2002).

${ }^{8}$ Rustan Ang y Pascua v. The Honorable Court OF Appeals and Irish Sagud, G.R. No. 182835, 20 April 2010

9 People of the Philippines V. Noel Enojas y Hingpit, et al., GR No. 204894, 10 March 2014

${ }^{10}$ MCC Industrial Sales Corporation v. Ssangyong Corporation, G.R. No. 170633, 17 October 2007

${ }^{11}$ People of the Philippines v. Al Sanchez. Vitangcol III and Wilson Tigno De Vera, SB-16-CRM-1207 and 1208,7 October 2019.

${ }^{12}$ Emmanuel B. Aznar v. Citibank, N.A., (Philippines), G.R. No. 164273, 28 March 2007.

${ }^{13}$ Aldy Nuez v. Elvira Cruz-Apao, A.M. NO. CA-05-18-P, 12 April 2005.

${ }^{14}$ Associate Justice Delilah Vidallon-Magtolis v. Cielito M. Salud, A.M. No. CA-05-20-P, 9 September 2005.
} 


\subsection{Framework of the Study}

ECA and REE served as the legal framework of the current paper. The former gives legal recognition to electronic forms of data messages, ${ }_{1}^{15}$ documents ${ }_{1}^{16}$ signatures ${ }_{1}{ }^{17}$ transactions, and storage of information. It provides penalties for access to data without consent, piracy, hacking, and other violations. ${ }^{18}$ REE provides a legal framework that addresses various concerns relative to electronic documents and transactions..$^{19}$ The most notable provisions of ECA that relate to the law of evidence are found in Chapter II of said Act under the title: Legal Recognition of Electronic Writing or Document and Data Messages. These provisions include Legal Recognition of Data Messages, ${ }_{1}^{20}$ Legal Recognition of Electronic Documents, ${ }^{21}$ Legal Recognition of Electronic Signatures, ${ }^{22}$ Presumption Relating to Electronic Signatures, ${ }^{23}$ Original Documents, ${ }^{24}$ Authentication of Electronic Data Messages and Electronic Documents, ${ }^{25}$ Admissibility and Evidential Weight of Electronic Data Message and Electronic Documents, ${ }^{26}$ Retention of Electronic Data Message and Electronic Document, ${ }^{27}$ Proof by Affidavit, ${ }^{28}$ and Cross-Examination. ${ }^{29}$ Basically, REE provides for the rules on the admissibility and authentication of electronic evidence.

The foregoing legal framework served as the lens of the present study when it explored the application of REE based on the experience of the respondent trial court judges and litigation lawyers. The term "electronic document" may be used interchangeably with "electronic data message." ${ }^{\prime 30}$ REE defines the characteristics of electronic evidence, taking into account the variations of EE and their kinds vis-à-vis its relevance in the digital world. It bears stressing that the foregoing definition served as the operational definition of electronic evidence in the study.

\subsection{Methods}

Research Design. The present study utilized basic qualitative research (Merriam, 2009). Qualitative research refers both to techniques (of data collection or data analysis) and to a wider framework for conducting research or paradigm. A paradigm provides an overarching framework for research (Clarke \& Braun, 2013). In the present study, both senses of qualitative research as techniques and as a paradigm were used. Following the rigors of qualitative research, the phenomenon under investigation was the application and use of REE in the courts of law under the Philippine jurisdiction. ${ }^{31}$

Participants in the Study. In this present study, 29 litigation lawyers (10 male and 19 female) and 13 trial judges (three male and ten female) in Cavite and Metro Manila resulted from purposeful sampling. All the litigation-lawyer participants were actively practicing law. They had a chance to litigate cases that involved the employment of REE. In contrast, all the trial-judge participants had handled cases that involved the appreciation of electronic evidence.

Data Collection Technique and Procedure. Originally, the interview was planned to be the primary data collection technique. However, given the unavailability of all the participant-litigation lawyers and trial judges for interview sessions due to their workload, the researchers judiciously shifted to a qualitative survey. The survey questionnaire was administered through Google Docs. A link to the survey was sent to the participants, whereby they were redirected to the questionnaire page online. Responses were retrieved through a feature of Google Docs where the system itself consolidated the responses on a downloadable zipped folder.

For ethical considerations, the acquiescence of all the participants was given to the researchers after explaining to them the purpose and value of the present study and assuring them of maintaining their anonymity and the confidentiality of their responses throughout the entire conduct of the

\footnotetext{
${ }^{15}$ Republic Act No. 8792 (2000), Sec. 6.

${ }^{16}$ Republic Act No. 8792 (2000), Sec. 7

${ }^{17}$ Republic Act No. 8792 (2000), Sec. 8.

${ }^{18}$ Republic Act No. 8792 (2000), Sec. 33

${ }^{19}$ A.M. No. 01-7-01-SC [July 17, 2001].

${ }^{20}$ Republic Act No. 8792 (2000), Sec. 6

${ }^{21}$ Republic Act No. 8792 (2000), Sec. 7

${ }^{22}$ Republic Act No. 8792 (2000), Sec. 8

${ }^{23}$ Republic Act No. 8792 (2000), Sec. 9

${ }^{24}$ Republic Act No. 8792 (2000), Sec. 10

${ }^{25}$ Republic Act No. 8792 (2000), Sec. 11

${ }^{26}$ Republic Act No. 8792 (2000), Sec. 12

${ }^{27}$ Republic Act No. 8792 (2000), Sec. 13

${ }^{28}$ Republic Act No. 8792 (2000), Sec. 14

${ }^{29}$ Republic Act No. 8792 (2000), Sec. 15

${ }^{30}$ Rules on Electronic Evidence, Rule 2, Sec. 1 (h).

${ }^{31}$ A.M. No. 01-7-01-SC. - Re: Rules on Electronic Evidence.
} 
research until its publication and post-publication. They were also assured that all collected data would be treated according to the data privacy law and pertinent laws. Lastly, the researchers declare the absence of conflict of interest in the conduct and publication of the study.

Data Analysis. Frequency was employed particularly to the participant's responses to the closeended questions. Their essay-like answers to the open-ended questions were analyzed following the three phases of basic qualitative data analysis, namely, open coding, axial coding, and selective coding (Merriam, 2009). The first phase involved a thorough analysis of the individual responses of the participants. At this phase, significant statements were identified from which initial categories were sifted. In the second phase, axial coding, the initial categories were carefully compared across responses of the participants of the study. The analysis resulted in a master list of categories.

Finally, in the selective coding, the categories were fine-tuned and finalized following Ballena and Liwag's (2019) CERES criteria such as (1) conceptual congruence, making sure that the categories belonged to the same level of abstraction; (2) exclusivity, ensuring that the final categories mutually excluded one another and those that did not were lumped together; (3) responsiveness, ensuring that the final categories were the appropriate answers to the specific objectives of the study; (4) exhaustiveness, ensuring that all the potential categories from the qualitative data were reflected in the final list; and (5) sensitivity, ensuring that the final categories found support from the raw data.

\subsection{Results}

\section{Cases Involving Electronic Evidence}

The results showed that the majority of the litigation lawyers had less than 20 cases in which the electronic evidence they presented had been admitted by the court. The minority, on the other hand, said that no court had ever admitted the electronic evidence they had presented. As to the trial judges, all but one answered that they had not admitted, at the moment, any electronic evidence submitted before them. Electronic evidence was more commonly presented in criminal cases and a few in civil cases. All participants in the study did not use electronic evidence in special proceedings or in quasi-judicial and administrative cases.

Text messages were the most frequently used and presented in court as evidence of a party according to the participant-litigation lawyers and participant-trial judges. Electronic evidence was also in the form of E-mails and Facebook/Messenger. Finally, CCTV footage, online programs, and electronic book of accounts were the least EE presented in court.

\section{Application of the Rules on Electronic Evidence}

The most commonly applied REE provision is Rule 3, Section 2, which pertains to the admissibility of electronic documents. This is followed by Rule 5, Section 1, referring to the burden of proving authenticity; Rule 5, Section 2, on the manner of authentication; and Rule 6, Section 2, about the authentication of electronic signatures. It is to be noted that all these provisions pertain to the "authenticity" of electronic evidence. This only shows that, indeed, the primary concern with respect to electronic evidence is its authenticity.

Trial judges found it most difficult to apply Rule 3, Section 2, which relates to the admissibility of electronic documents. Additionally, they found it difficult to apply Rule 5, Section 1, providing for the burden of proving authenticity, and Rule 5, Section 2, on the manner of authentication. Again, both of these provisions refer to the procedure for authenticating electronic evidence. The other provisions that the trial judges found difficult to apply include Rule 3, Section 3, on the privileged communication of electronic documents, and Rule 6, Section 2, on the authentication of electronic signatures.

A thorough analysis of the qualitative data following the three phases of the analysis revealed

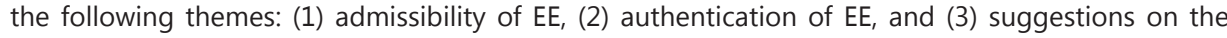
implementation of REE.

\section{Admissibility of EE}

The electronic evidence being inadmissible was primarily the common objection encountered by the respondents as to the presentation of electronic evidence. The foremost objection encountered by the respondents as to the presentation of electronic evidence was the electronic evidence being inadmissible, followed by no proper authentication. All of these objections relate to the Rules pertaining to the admissibility of electronic evidence. 
Both the trial judges and litigation lawyers' primary reason for the non-admission of the same was the failure to properly authenticate the electronic evidence presented. Among the other reasons given by the litigation lawyers and trial judges were the doubtful credibility of the electronic evidence, "no showing of its due execution," and its "not being relevant to the case."

The views of the litigation lawyers with respect to the admissibility of electronic evidence in light of REE were categorized into six: (1) difficulty in applying REE, (2) construction of REE, (3) improvement of REE, (4) uniformity in the application of REE, (5) doubtfulness of EE, and (6) admissibility of EE. The following extracts support the foregoing categories:

Extract 1. "It is difficult to administer electronic evidence as evidence in court."

Extract 2. "The REE is not properly construed."

Extract 3. "I think the law should be revised to be consistent with the current trends in authentication, security, and other technicalities involving online information. It must also coincide with the current status of social media usage."

Extract 4. "Judges have wide latitude in determining evidence showing its integrity and reliability."

Extract 5. "The advancement of technology electronic evidence can be easily fabricated."

Extract 6. "The admissibility of EE is highly relevant particularly in this time when all correspondences happen online and the only evidence of which is EE."

Additionally, there were no sufficient criteria in the Rules for the admissibility of electronic evidence as manifested in the following categories, which resulted from their responses: (1) ambiguity in the Rules on admissibility, (2) variations in the mode of proving its admissibility, (3) technicality of REE, (4) failure to cover all kinds of EE, and (5) improvement of REE. The following extracts support the foregoing categories:

Extract 7. "The criteria for admissibility of EE [are] actually vague; there is no clear standard to follow in determining the integrity and reliability of the EE. The REE gives full discretion to the judge without indicating standards to follow."

Extract 8. "There is no uniform standard on how to assess and admit the evidence."

Extract 9. "The law uses very technical language."

Extract 10. "It does not address advances in messaging applications where the sender can now edit a previously sent message."

Extract 11. "[The REE] must have clear and updated implementing rules."

\section{Authentication of EE}

Most of the participant-litigation lawyers and trial judges (86.21\%) said that there was no uniform procedure in different courts with respect to the application of REE as there were variations observed in court procedures. Only $13.79 \%$ of the respondents expressed otherwise. The results which revealed the variations in court procedures with respect to the authentication of electronic evidence were categorized into three: (1) authentication procedures, (2) leniency of the judges, and (3) appreciation of the judges. The following extracts support the foregoing categories:

Extract 12. "Presentation of original e-mails through computer. Some judges do not require [the same]."

Extract 13. "Some [judges] are lenient; others are strict."

Extract 14. "[Judges have] different appreciation of electronic evidence."

Some of the gaps in REE primarily related to the mode of its authentication during the trial. There was no specific provision in the Rules that discusses the competence of a witness who will authenticate a piece of EE or whether or not it is required to have an expert witness who would prove its authenticity, as in the other cases of documentary evidence. The following extracts reveal some 
gaps concomitant to authentication of electronic evidence:

Extract 14. "[There was] lack of expert witness to authenticate (for FB and other social media accounts)."

Extract 15. "In cases of cyber libel, when URL is needed, there are limits on what can be used as evidence. Phone screenshots are not enough."

Varying procedures in the authentication of electronic evidence were shown in the following extracts:

Extract 16. "Some courts require presentation of the original (on a device); others do not. Some courts do not get into the nitty-gritty details on authentication."

Extract 17. "Some courts require parole evidence of authorship. Some do not strictly observe authentication procedure."

The process of authenticating electronic evidence was the foremost concern of the lawyers. With respect to authentication, no similar procedures were followed. The mode of authentication in one court may not be followed in another court.

\section{Suggestions on the Implementation of REE}

Table 1 presents the thematic suggestions put across by the lawyer-participants.

Table 1. Lawyers' Suggestions Regardingthe Implementation of the REE

\begin{tabular}{|c|c|}
\hline Main Themes & Illustrative Quotations \\
\hline Authentication & $\begin{array}{l}\text { - Set definite standards as to admissibility and authentication. } \\
\text { - Fiscals should also be lenient. They want NBI authentication. } \\
\text { - Who needs that in PH? } \\
\text { - Set further parameters and clearer guidelines. } \\
\text { - Electronic evidence should be properly identified and its due } \\
\text { execution. } \\
\text { - All judges should allow normal ways of authentication. }\end{array}$ \\
\hline $\begin{array}{l}\text { Language of } \\
\text { the REE }\end{array}$ & $\begin{array}{l}\text { - Simplify the language of the REE. } \\
\text { - Make the rules on admissibility simple and not too technical for } \\
\text { the litigants. } \\
\text { - Delete phrase in S1 R4, which says, "shown to reflect the data } \\
\text { accurately." This should already be presumed and need not be } \\
\text { shown by the proponent. It will just make litigation costly. The } \\
\text { burden of proof that data is not accurately reflected should be } \\
\text { on the opponent. }\end{array}$ \\
\hline $\begin{array}{l}\text { Uniformity of } \\
\text { procedures }\end{array}$ & $\begin{array}{l}\text { - Come up with a uniform standard in authenticating EE. } \\
\text { - There should be a uniform interpretation of the rules. }\end{array}$ \\
\hline $\begin{array}{l}\text { Training and } \\
\text { revisions }\end{array}$ & $\begin{array}{l}\text { - It should be explained or discussed more. } \\
\text { - Amend the provisions after consultations with the bar and } \\
\text { bench. Then, technical training for judges. } \\
\text { - My suggestion is more on revisions. But as to implementation, } \\
\text { my suggestion is continuous training with practical exercises. } \\
\text { Classroom instructions will not suffice. }\end{array}$ \\
\hline $\begin{array}{l}\text { Collaboration } \\
\text { with technical } \\
\text { experts }\end{array}$ & $\begin{array}{l}\text { Review of the IRR; application and expertise in the area of } \\
\text { technology. }\end{array}$ \\
\hline $\begin{array}{l}\text { Information } \\
\text { dissemination }\end{array}$ & $\begin{array}{l}\text { - The internet service providers should, likewise, be tapped to } \\
\text { identify the user of service or internet for additional evidence. } \\
\text { - The IRR should be disseminated widely for everybody's } \\
\text { instruction. }\end{array}$ \\
\hline
\end{tabular}


The suggestions lawyers have regarding the "Rules on Electronic Evidence" generally covered the following: (1) authentication, (2) language of the REE, (3) uniformity of procedures, (4) training, (5) collaboration with technical experts, and (6) information dissemination.

The trial judges strongly suggested the need for the Supreme Court to further set definite standards as to the admissibility and authentication of electronic evidence. It is also suggested that the Rules should be explained or discussed more, that the Supreme Court should set further parameters and clearer guidelines on the implementation of the Rules, that electronic evidence should be properly identified, and proof of its due execution simplified. They saw the need to institute a uniform standard in authenticating electronic evidence.

Finally, as to the language of the Rules, the respondents saw the need to simplify the language of the Rules; the Supreme Court should make the rules on admissibility of electronic evidence simple and not too technical.

\subsection{Discussion}

Admissibility of electronic evidence in the courts of law and its authenticity are the two central aspects of electronic evidence subject not only to scholarly discourse but, more importantly, to legal and administrative proceedings (Didace, 2021; Tosza, 2020; Jackson, 2021; Novak et al., 2018; Khudhair, 2021; Makulilo, 2018; Mohamad, 2019; and Kančauskienè, 2019). In consonance with the foregoing studies, both the lawyer- and the trial judge-participants underscored the paramountcy of the admissibility and authenticity of electronic evidence presented in courts. However, both participants concurred in the observation relating to the vagueness of REE provisions on admissibility. ${ }^{32}$ The vagueness in the law is filled by judges who tend to have variable appreciation and interpretation of the Rules. In other jurisdictions such as Tanzania, the vagueness of the law of electronic evidence has not been a problem, rather the limited application of the rule on admissibility in civil proceedings (Didace, 2021).

Additionally, in Zanzibar, which is part of the United Republic of Tanzania, one critical challenge relative to the authentication of digital evidence points to its susceptibility to alteration or copying; thus, the need for "a higher threshold level of authentication of digital evidence is required" (Makulilo, 2018, p. 49). The same finding has been highlighted in the present study in the context of the Philippine jurisdiction. The vulnerabilities of electronic evidence have also been stressed in the jurisdiction of the United Kingdom (Makulilo, 2018).

By and large, the present study explored the frontiers in REE under the Philippine jurisdiction pivoting around the cases involving electronic evidence, application of REE, its admissibility and authentication, and suggestions on the implementation of REE. ${ }^{33}$ It could provide a valuable contribution to the existing literature on electronic evidence in law.

\subsection{Conclusion}

With the enactment of the "Electronic Commerce Act" by Congress in 2000 and the promulgation of "Rules on Electronic Evidence" by the Supreme Court in 2001, the Philippine jurisdiction has been in keeping with other countries across the globe with respect to electronic evidence. Notwithstanding the two-decade life of the Act and the Rules, a dearth of cases on electronic evidence has formed part of the Philippine jurisprudence. A fortiori the significance of the present study which focused on REE. The vagueness of REE provisions on the admissibility of electronic evidence results in varying interpretations of judges, which ultimately affect their appreciation of the evidence presented at trial. Corollary, lawyers' failure to understand such provision bars them from presenting important

\footnotetext{
${ }^{32}$ One very important development in the Philippine jurisdiction has been the promulgation by the Supreme Court of the 2019 Amendments to the 1989 Revised Rules on Evidence [A.M. No. 19-08-15-SC], which took effect on May 1, 2020. Significant provisions, albeit minimal, relate to electronic evidence such as Section 2. Documentary evidence. (the addition of recordings and photographs and those included within the purview of the latter such as "pictures, drawings, stored images, $x$-ray films, motion pictures or videos.") Section 3. The original document must be produced, exceptions, and Section 4. Original of the document (particularly paragraphs [a] and $[b])$.

${ }^{33}$ The suggestions relative to the REE put forward by the participant lawyers, and trial judges would indeed be worth noting by the Supreme Court. Chief Justice Peralta himself underscored that "the continuous revision and issuance of rules of procedure so as to make the law more responsive and accessible to the needs of court-users, and the conduct by the Philippine Judicial Academy (PHILJA) of more skills-based training for judges and court personnel." Supreme Court of the Philippines. (2020). 2019 amendments to the 1989 Revised Rules on Evidence (A.M. No. 19-08-15-SC), p. iii. The current leadership of the Philippine Judiciary is indeed open to revision of existing rules for as long as revisions and amendments "simplify and expedite judicial proceedings". Ibid. In the same vein, [an effective court system] must adapt to the changing times, apply effective methods of dispute resolution. There must be continuous training of judges, lawyers, and litigants on core values of speedy resolution of cases" Message of Associate Justice Alexander G. Gesmundo. Ibid. p. iv.
} 
electronic evidence at trial.

In addition, authentication is a big challenge that confronts both litigation lawyers and trial judges; attendant to this challenge is the susceptibility of electronic evidence to alteration. Finally, suggestions on the admissibility and authentication provisions expressed by lawyers and judges are deemed valuable when REE is to be revisited and revised by the Supreme Court.

\subsection{Limitations of the Study}

Notwithstanding the successful conduct of the study, it had limitations being the first empirical study on REE. The study focused solely on REE as applied in judicial proceedings. While the participants came only from the National Capital Region and the Province of Cavite, the limited generalizability of significant findings of the study could be justified by the exploratory nature of the research.

\subsection{Future Research}

Given the foregoing limitation of the paper, some suggestions for future research are provided. First, the present study focusing on the application of REE in judicial proceedings could be replicated by having litigation lawyers and judges in other regions of the country as participants in the study. Second, exploratory research on REE as applied to quasi-judicial and administrative proceedings could be done. Third and last, quantitative type of studies on REE may be undertaken. In so doing, scholarly discourse on electronic evidence law shall continue.

\subsection{Declaration of Conflicting Interests}

The authors declared no potential conflicts of interest with respect to this article's authorship and/or publication.

\subsection{Funding}

The authors received no financial support for the research and/or authorship of this article.

\section{REFERENCES}

Administrative Matter. No. 01-7-01-SC. (2001 July 17). Rules on electronic evidence.

Administrative Matter. No. 19-08-15-SC, 2019. (2020, May 1). Amendments to the 1989 revised rules on evidence.

Administrative Matter. No. 19-08-15-SC. (2020). 2019 amendments to the 1989 revised rules on evidence.

Administrative Matter. No. CA-05-18-P. (2005 April 12). Aldy Nuez v. Elvira Cruz-Apao.

Administrative Matter. No. Ca-05-20-P. (2005 September 9). Associate Justice Delilah Vidallon-Magtolis v. Cielito M. Salud.

Aldy Nuez v. Elvira Cruz-Apao, A.M. NO. CA-05-18-P, 12 April 2005.

Associate Justice Delilah Vidallon-Magtolis v. Cielito M. Salud, A.M. No. CA-05-20-P, 9 September 2005.

Ballena, C. T., \& Liwag, E. F. (2019). Carpe diem or carpe thesis? How graduate students deal with their thesis writing. International Journal of Research, 6, 68-76.

Clarke, V., \& Braun, V. (2013). Successful qualitative research: A practical guide for beginners. Sage Publications, Inc.

Didace, D. (2021). Electronic evidence in Tanzania and its challenges. https://www.grin.com/document/1021307.

Emmanuel B. Aznar v. Citibank, N.A., (Philippines), G.R. No. 164273, 28 March 2007.

Jackson, M. (2021). An approach to the judicial evaluation of evidence from computers and computer systems. Digital Evidence and Electronic Signature Law Review, 18 pp. 50-55. https://doi.org/10.14296/deesIr. v18i0.5289

Kančauskienè, J. (2019). Computer forensics and electronic evidence in criminal legal proceedings: Lithuania's experience. Digital Evidence and Electronic Signature Law Review, 16, 11-24. https://doi.org/10.14296/deesIr. v16i0.5015.

Khudhair, N. S. (2021). Revisiting the admissibility of electronic evidence: Indian jurisdictions and notes from other countries. Psychology and Education, 58(5), 1135-1148.

Kramer, X. (2018). Challenges of electronic taking of evidence: Old problems in a new guise and new problems in disguise. Il Conferencia Internacional \& XXVI Jornadas Iberoamericanas de Derecho Procesal IIDP \& IAPL, La Prueba en el Proceso.

Makulilo, A. B. (2018). The admissibility and authentication of digital evidence in Zanzibar under the new evidence act. Digital Evidence and Electronic Signature Law Review, 15, pp. 48-59.

MCC Industrial Sales Corporation v. Ssangyong Corporation, G.R. No. 170633, 17 October 2007.

Merriam, S. B. (2009). Qualitative research: A guide to design and implementation. John Wiley \& Sons, Inc 
Mohamad, A. M. (2019). Admissibility and authenticity of electronic evidence in the courts of Malaysia and United Kingdom. International Journal of Law, Government, and Communication, 4(15), 121-129. https://doi. org/10.35631/ijlgc.4150013

Novak, M., Grier, J. \& Gonzalez, D. (2018). New approaches to digital evidence acquisition and analysis. NIJ Journal, 280, 1-7, https://www.nij.gov/journals/280/ pages/new-approaches-to-digital-evidenceacquisitionand-analysis.aspx.

People of the Philippines v. Al Sanchez. Vitangcol III and Wilson Tigno De Vera, SB-16-CRM-1207 and 1208, 7 October 2019.

People of the Philippines V. Noel Enojas y Hingpit, et al., GR No. 204894, 10 March 2014.

Polish Code of Civil Procedure. (2014).

Republic Act No. 8792. (2000 June 14). Electronic Commerce Act of 2000.

Rules of Court. (1989). Revised rules on evidence.

Rustan Ang y Pascua v. The Honorable Court OF Appeals and Irish Sagud, G.R. No. 182835, 20 April 2010.

The Sedona Canada Principles. (2015), Sedona Conference Working Group 7, 2008 CanLIIDocs 1, <https://canlii. $\mathrm{ca} / \mathrm{t} / \mathrm{nf}>$, retrieved on 2021-11-25.

Tosza, S. (2020). All evidence is equal, but electronic evidence is more equal than any other: The relationship between the European Investigation Order and the European Production Order. New Journal of European Criminal Law, 11, 161 - 183.

Wang, M. (2008). Electronic evidence in China. Digital Evidence and Electronic Signature Law Review, vol. 5, 2014. https://doi.org/10.14296/deeslr.v5i0.1822.

\section{Correspondence:}

JANICE L. ANDRADE-UDARBE

https://orcid.org/0000-0001-5420-0268

judgejaniceodarbe@gmail.com

CONSTANTINO T. BALLENA*

constantinoballena@gmail.com

https://orcid.org/0000-0002-8772-0881

*Corresponding Author 